\title{
Biology and larval morphology of the genus Ceramida Baraud (Coleoptera: Melolonthidae: Pachydeminae)
}

\author{
Isabel Sanmartín
}

Sanmartin, I. 2007: Biology and larval morphology of the genus Ceramida Baraud (Coleoptera: Melolonthidae: Pachydeminae). — Entomol. Fennica 18: $117-125$.

The biology and larval morphology of Ceramida, a pest of olive trees in southern Spain, are described. The life-cycle is multivoltine, spanning three years in the field. Females lay eggs in the early spring, with the highest larval densities in June. Larvae feed on the root system of plants. Pupation takes place in the late summer. Adults emerge with the first autumnal rainfalls, with mating extending from September to January. Larval characters such as type of head pubescence, shape of antennal sensory areas, chaetotaxy of raster, and degree of reduction of metathoracic claws are of taxonomic value within Pachydeminae.

I. Sanmartin, Department of Systematic Zoology, Evolutionary Biology Centre, Uppsala University, SE-75236 Uppsala, Sweden; Email: isabel.sanmartin (a)ebc.uu.se

Received 9 May 2006, accepted 23 August 2006

\section{Introduction}

Larvae of the family Melolonthidae (Coleoptera, Scarabaeoidea) or "white grubs" are well-known pests of crops and underground stems of plants (Ritcher 1966). The subfamily Melololonthinae includes such important agricultural pests as Melolontha Fabricius, 1775, in Europe or Phyllophaga (Harris, 1827) in North America. In contrast, the subfamily Pachydeminae Reitter, 1902 did not include any species of economic interest until recently (Ritcher 1966, Serrano et al. 1996). The Pachydeminae comprise around 115 genera and 530 described species worldwide and have a cosmopolitan but spatially disjunct distribution (Sanmartín 2003). Rarity of specimens in entomological collections and the high overall similarity among species has made taxonomic identification very difficult (Baraud 1992). Phylogenetic relationships are in general poorly resolved. Recently, Sanmartín and Martín-Piera (2003) re- viewed the systematics of the Palearctic Pachydeminae and proposed the first phylogenetic classification for these genera.

Unlike economically important Melolonthidae such as Phyllophaga (Aragón-García et al. 2005), little is known on the biology and larval morphology of Pachydeminae species. Sporadic biological observations indicate that larvae are root-feeders (probably on grasses) and that mating occurs during autumnal rainfalls, after which males die and females dig into the ground for overwintering (Cobos 1951, Branco 1981, López-Colón 1993, Lacroix 2000, Vincini et al. 2000). Detailed larval descriptions exist only for the Nearctic genus Phobetus Le Conte, 1856 (Ritcher 1966) and the Neotropical Myloxenoides Martínez, 1975 (Vincini et al. 2000). Among the Palearctic genera, larval morphology has been described for Tanyproctus Faldermann, 1835 and Hemictenius Reitter, 1897 (Medvedev 1952, 1960) and Pachydema Castelnau, 1832 (Lacroix 
2000). However, these descriptions do not provide usually enough detail to allow systematic comparison with the New World genera.

Ceramida Baraud, 1987 is a small genus of Pachydeminae endemic to the southwestern Iberian Peninsula and the North African coast (Sanmartín \& Martín-Piera 1999). Species identification has traditionally been based on the male adult morphology, with females described for only a few species. Lack of reliable diagnostic characters has led to the description of many taxa on specimen or interpopulation differences (Baraud 1992). The difficulty in delimiting species boundaries lies in the high variability of the external morphology coupled with the absence of useful structural characters in the genitalia (Sanmartín \& Martín-Piera 2003). In the most recent taxonomic revision of the genus, Sanmartín and Martín-Piera (1999) used multivariate statistical analysis of quantitative characters to recognise eleven species within Ceramida. However, intermediate forms have been found in some species complexes, raising the possibility of even more synonymies (Sanmartín, unpublished).

The larval morphology of Ceramida has never been described and only a few observations exist on the biology of species (Cobos 1951, Branco 1981, López-Colón 1993). The genus was considered of no economic interest until 1993, when a new pest of white grubs was reported in olive fields in southern Spain, Seville (Alvarado et al. 1996), identified as Ceramida adusta (Kraatz, 1882) and Ceramida cobosi (Báguena, 1955). From 1994 to 1996, field studies (Serrano et al. 1996) and a parallel breeding program in the laboratory were carried out in order to understand the behaviour of the pest species. This provided us with the first opportunity to study the biology and larval morphology of Pachydeminae species in detail.

Here I provide the first description of the larval morphology of Ceramida species and compare this description with that of other Pachydeminae genera in order to find characters of possible systematic value. Verdú et al. (2004) recently showed that larval characters can be useful in elucidating phylogenetic relationships within Scarabaeoidea. I also review the biology of Ceramida species based on laboratory studies of the pest species Ceramida cobosi and $C$. adusta as well as published field observations on these (Serrano et al. 1996) and other species (Cobos 1951, Branco 1981, López-Colón 1993).

\section{Material and methods}

\subsection{Collection}

Sixty-two eggs, 54 second-instar larvae, and 110 male adults of Ceramida cobosi and C. adusta were collected in infested olive fields in Utrera and Morón (Seville) between 1994 and 1995. Adults were collected directly on the ground after a rainfall, or using interception traps, i.e., a plastic tray filled with water, buried to its rim in the soil, and attached to a $1 \mathrm{~m}$ vertical net (Serrano et al. 1996). A female of C. cobosi was also collected from the ground. It laid two eggs that did not hatch and were fixed for morphological study.

\subsection{Laboratory breeding}

Twenty-two of the eggs hatched after 15-30 days of development. From 1994 to 1996, the newly emerged larvae, and the collected 54 second larval instars, were reared inside cylindrical glass containers (11 cm high, $8 \mathrm{~cm}$ wide) filled with moist soil from the study area, and previously sterilised to prevent nematode infestation. The breeding cages, with one specimen each, were kept in a climatic chamber at the Museo Nacional Ciencias Naturales, Madrid, Spain (MNCN), with a temperature of $21^{\circ} \mathrm{C}$ and $90 \% \mathrm{RH}$. Cages were examined weekly under red light exposure $(60 \mathrm{~W})$ to minimise disturbance, and the number and stage of living larvae recorded. Second and third-instar larvae were fed with fresh carrot roots; first larval instars probably fed on the soil organic material. Larval mortality was very high, and only two larvae were reared to adulthood: a male adult of C. adusta (April 1995) and a female of C. cobosi (October 1996).

\subsection{Larval morphology}

Fifteen third-instar larvae from the studied area were fixed in KAAD solution (Carne 1951) for eight hours, and then preserved in $70 \%$ ethanol 
for morphological study. The external morphology was studied under a binocular stereomicroscope. Mouthparts and raster were examined under a light microscope. After removal, the structures were cleared in boiling distilled water and a $5 \% \mathrm{KOH}$ solution, and mounted on a microscopic slide with Euparal ${ }^{\circledR}$ mounting medium. Illustrations were made using a camera lucida attached to the microscope, and a video camera was used for both viewing and photographing finer details. Voucher specimens are deposited in the entomological collection of the MNCN. In addition, before starting the rearing experiment I examined all 54 second-instar larvae under the stereomicroscope in order to find possible morphological differences.

\section{Results}

\subsection{Description of the larval morphology of Ceramida species}

No morphological differences were found between the 15 fixed third-stage larvae or any of those used in the rearing experiment. Verdú et al. (2004) noted that larval characters in Scarabaeoidea show very little variation at low taxonomic levels and appear to be more conservative than those of adults. For example, Micó et al. (2001) found no larval differences between the Anisopliini genera Anisoplia Schöenher and Anthoplia Medvedev but a new phylogenetic analysis based on adult morphology (Jameson et al. in press.) confirms that they are two distinct lineages. Sanmartín and Martín-Piera (1999) distinguished Ceramida cobosi from $C$. adusta on the basis of morphometric characters of the adults such as the length of the antennal club relative to body size and the shape of the clypeus. However, we have found populations in Seville with intermediate morphological characters between these two species (Serrano et al. 1996, Sanmartín, unpublished), suggesting that $C$. cobosi and $C$. adusta could be two different "forms" within a highly polymorphic species. In the wait of new taxonomic studies to clarify their status, the following larval description refers to the third-stage larvae of both Ceramida cobosi and C. adusta. Terminology for larval structures follows Ritcher
(1966). The mean of range measurements in millimetres is given between parentheses (sample size $=10$ individuals).

Body (Fig. 1a): Length (35.96 \pm 2.25$)$, maximum width $(6.91 \pm 0.65)$. Cylindrical and typically scarabeiform (C-shaped), more stylised than in other Melolonthidae genera. Three thoracic segments and 10 abdominal segments.

Spiracles (Fig. 1b): One pair of spiracles in the prothorax (TS) and first eight abdominal segments (AS, Fig. 1a). Thoracic spiracles slightly larger $(0.91 \times 0.20)$ than the first five abdominal spiracles $(0.72 \times 0.18)$ and twice as large as those in the three last abdominal segments $(0.52 \times$ $0.16)$. Respiratory plate (RP) C-shaped and "slightly constricted" (i.e., the distance between the two lobes of the respiratory plate ranging between 100 to 80 percent of the dorso-ventral diameter of the bulla, Ritcher 1966), facing posteriorly in TS, and anteriorly in AS; numerous microscopic respiratory holes. Bulla (B) large and oval.

Head capsule (Fig. 1c): Maximum width $(5.26 \pm 0.35)$. Cranium: narrower than prothorax, surface yellowish-brown, finely reticulate. Frons (F) with one eyespot or "stemmata" (O) on each anterior side. Clypeus (C): trapezoidal and narrow, with a distinct clypeo-frontal suture (CS) bounded laterally by the precoilae (PCL). Labrum: (L) symmetrical, with an oval anterior margin, not trilobed. Frons, clypeus, and labrum covered anteriorly with long, fine setae, interspersed with short, "club"-shaped setae. Epicranium (E), clypeus, and labrum covered laterally by a dense pubescence of long microsetae. Mandibles (M) with broad, sharp-pointed setae.

Antennae (Fig. 1d): Four-jointed, borne on a short basal piece (BP) partially fused to the epicranium and dorsally covered with microsetae. First segment about as long as the second, with a few long setae dorsally. 3rd segment produced on the inner side into a conical process. Apical segment fusiform, half the size of the others, covered on the dorsal and ventral side by "thread"-shaped sensory spots (SS). A ring of olfactory pegs $(\mathrm{P})$ at the apex.

Maxilla (Figs. 1e-f): Galea (GA) and lacinia (LA) not fused in a mala but fitting tightly together. Galea with a large uncus at the apex (GU) and a group of four unci-like setae (S) dorsally. Lacinia with 3 unci (LU) at the middle, sur- 


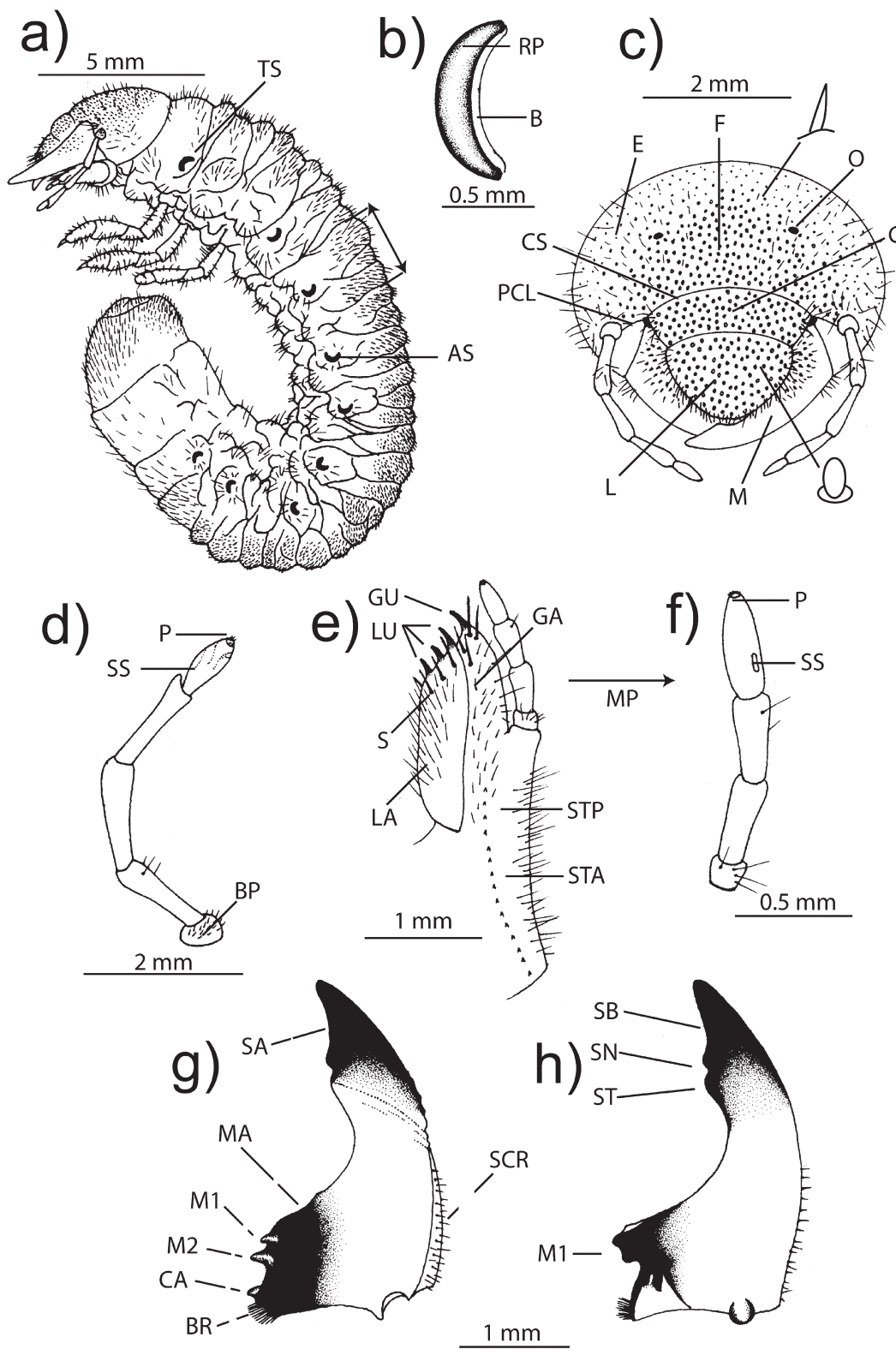

Fig. 1. Third-stage larvae of Ceramida. - a. Body, left lateral view. - b. Thoracic spiracle. $-c$. Head capsule (frontal view) with details of setae. $-d$. Antenna, lateral view and detail of sensory spots in last antennal segment. - e. Right maxilla, dorsal view. $-\mathrm{f}$. Maxillary palp, dorsal view. - g. Right mandible, dorsal view. - h. Left mandible, ventral view. Abbreviations: AS, abdominal spiracles; $B$, bulla; BP, antennal basal piece; BR, brustia; C, clypeus; CA, calx; CS, clypeo-frontal suture; $\mathrm{E}$, epicranium; $F$, frons; $G A$, galea; GU, uncus of galea; L, labrum; LA, lacinia; LU, uncus of lacinia; M, mandible; MA, mandible molar area; M1, first molar lobe; M2, second molar lobe; MP, maxillary palpus; $\mathrm{O}$ : stemmata, $P$, ring of olfactory pegs; PCL, precoilae; $\mathrm{RP}$, respiratory plate; $\mathrm{S}$, unci-like setae; $\mathrm{SA}$, mandible scissorial area; SB, mandible scissorial blade; $\mathrm{SCR}$, scrobe; SN, mandible scissorial notch; SS, sensory spots; ST, mandible scissorial tooth; STA, stridulatory area; STP, stipes; TS, thoracic spiracles.

rounded by a row of three unci-like setae $(\mathrm{S})$ on each side. Lacinia, galea, and stipes (STP) covered by long, fine setae. Stridulatory area (STA) consisting of a row of 15-16 small, truncated teeth. Maxillary palpus (MP) four-jointed, the apical segment with a sensorial elliptical area (SS) in the dorsal side and a ring of olfactory pegs (P) at the apex.

Mandibles (Figs. 1g-h): Asymmetrical, subtriangular in shape. Dark scissorial area (SA), consisting of a distal blade-like portion (SB) and a small proximal tooth (ST), separated by a scissorial notch (SN). Molar area (MA) strawcoloured, except for the dark molar structures. Right mandible (Fig. 3g) trilobed, with two small distal lobes (M1, M2) and a proximal elongated lobe or calx (CA). Left mandible (Fig. 3h) with a large, concave, bilobed distal lobe (M1). A brush of stout setae or brustia (BR) at the base. Subtriangular scrobe (SCR) covered with thick, 
a)

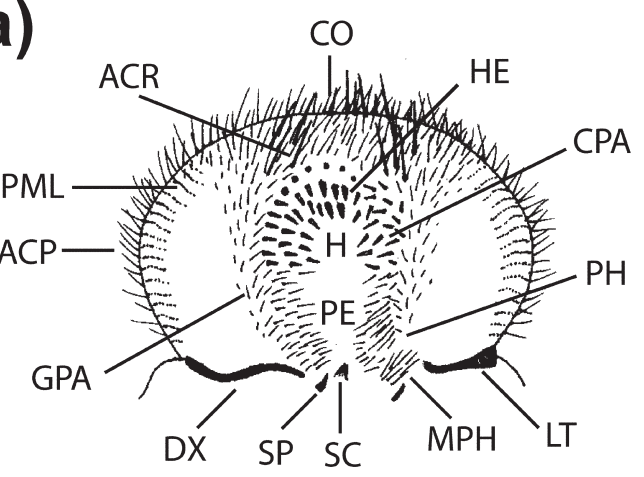

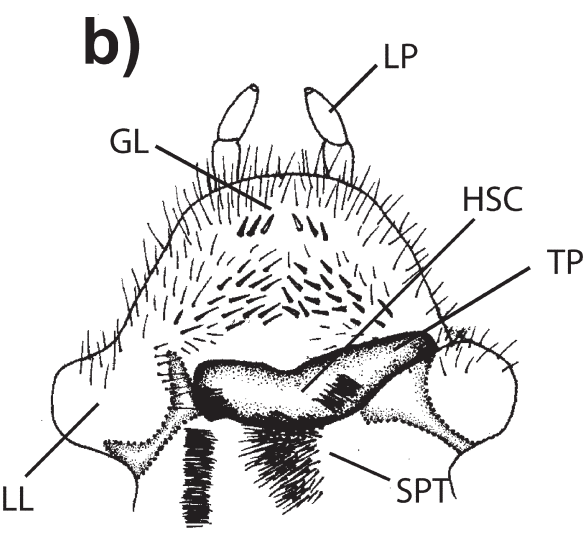

$1 \mathrm{~mm}$
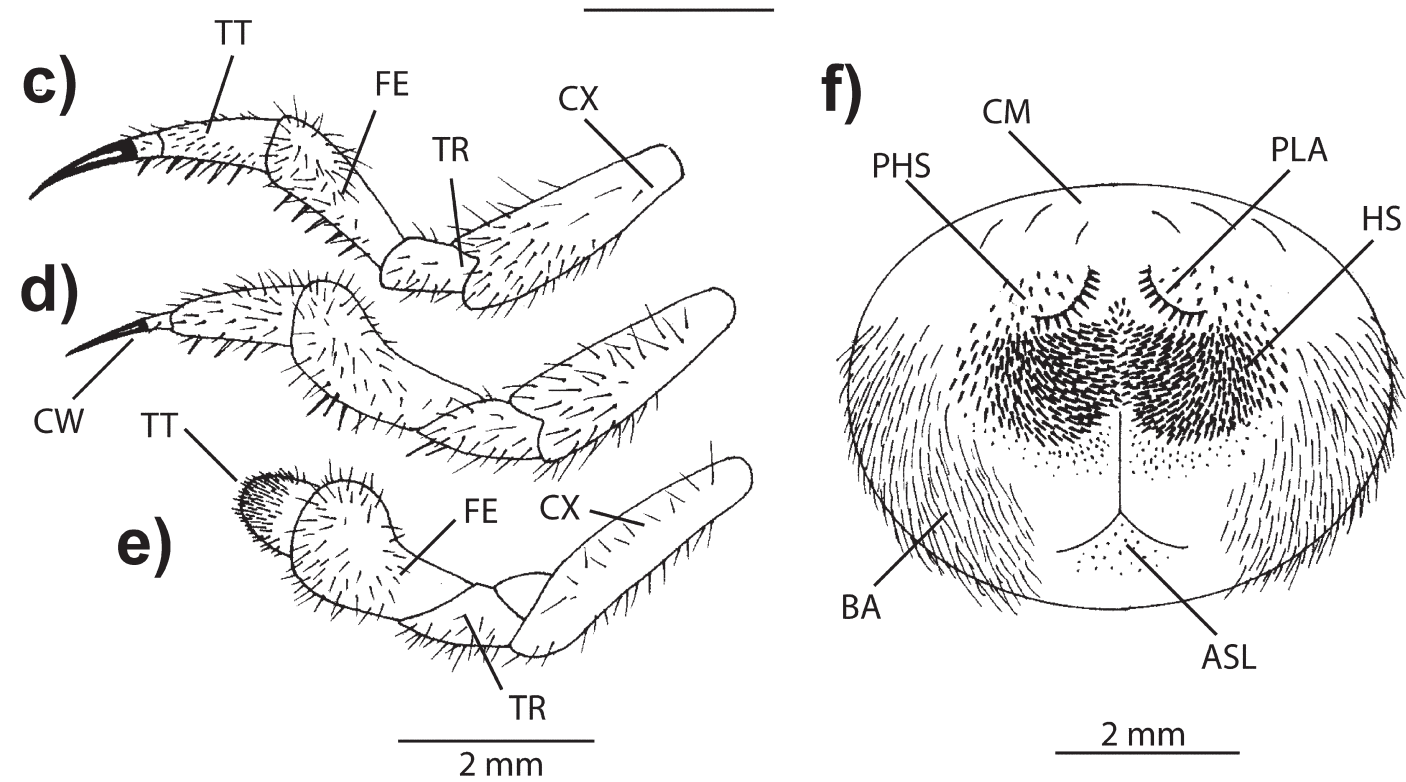

Fig. 2. Third-stage larvae of Ceramida. - a. Epipharynx. - b. Hypopharynx. - c. Prothoracic leg, lateral view. - d. Mesothoracic leg, lateral view. - e. Metathoracic leg, lateral view. - f. Raster. Abbreviations: ACP, acanthoparia; ACR, acroparia; ASL, anal slit; BA, barbulae; CM, campus; CO, corypha; CPA, chaethoparia; CW, claw; CX, coxa; DX, dexiotorma; FE, femur; GL, glossa; GPA, gymnoparia; H, haptomerum; HE, heli; HS, hamate setae; HSC, hypofaringeal-sclerome; LL, lateral lobe; LT, laeotorma; LP, labial palpus; MPH, mesophoba; PE, pedium; PH, phoba; PHS, preseptular hamate setae; PLA, palidia; PML, plegmatium; SC, sense cone; SP, sclerotized plate; SPT, setae patch; TT, tibia-tarsus; TP, truncated process; TR, trocanter.

sharp-pointed setae. Stridulatory area absent.

Epipharynx (Fig. 2a): Broader than long, with rounded lateral margins. Corypha $(\mathrm{CO})$ not protuberant at the apex, bearing a row of six thick setae. Acroparia (ACR) with 2-3 pairs of long, thick setae on each side of corypha, and numerous small, finer setae. Plegmatium (PML) present, consisting in 16-17 plegmata. Acanthoparia (ACP) with setae more numerous and finer than in other genera. Gymnoparia (GPA) with short, fine setae. Chaethoparia (CPA) covered with short, thick setae, more abundant on the left side. Haptomerum $(\mathrm{H})$ with two transverse rows of large heli (HE), 3 above and 2 below, and a slightly curved, transverse row of 6 small teeth over the heli. Pedium (PE) ovate, with a dense row of long microsetae on each side, forming the phoba (PH). Dexiotorma (DX) sinuated; laeotorma (LT) semitriangular. Nesia composed of a blade-like sclerotized plate (SP) and a sensorial 
cone (SC). Mesophoba (MPH) consisting of a thick brush of long microsetae, and a "spinelike", small sclerotized structure.

Hypopharynx (Fig. 2b): Fleshy, cushion-like glossa (GL) covered with fine setae; distally a row of three straight, pointed setae on each side; disc with 16-17 finer setae arranged in 2-3 rows on each side. Hypopharyngeal sclerome (HCL) asymmetrical, with well-developed truncate process (TP) on right side, a basal patch of thick setae (SPT) on each side; two more patches located below. Lateral lobes (LL) with 8-9 fine setae on each. Labial palps (LP) two-jointed and with a ring of olfactory pegs at the apex.

Legs (Figs. 2c-e): Four segmented, each segment covered with long setae: long cylindrical coxa (CX), short trocanter (TR), distally broader femur (FE), and fused tibia-tarsus (TT). Prothoracic and mesothoracic legs (Figs. 2c-d) well-developed, ending in a claw or tarsungulus $(\mathrm{CW})$, which is divided into a basal section covered with setae and a black, sharp-pointed distal section. Metathoracic leg (Fig. 2e) strongly modified: femur produced dorsally into a "hump-like" process; metathoracic claw absent, with tibia-tarsus ending in a highly dense, setose area.
Raster (Fig. 2f): Anal slit (ASL) Y-shaped. Palidia (PLA) arch-shaped, with each palidium composed of 12 depressed pali arranged in a curved, transverse row on each side of the anal slit, resembling brows. Hamate setae (HS) forming a thick patch under each palidia. Over the palidia, scattered, short preseptular hamate setae (PHS). Lateral surface of raster covered with long, fine setae or barbulae (BA). Broad campus (CM) with a few long, scattered setae.

\section{Discussion}

\subsection{Comparison with other Pachydeminae genera}

Based on the larval morphology of Phobetus comatus Barret, 1933, Ritcher (1966) proposed a raster with two pairs of longitudinal palidia and a haptomerum with five or more heli as diagnostic larval characters of the Pachydeminae. Vincini et al. (2000) described a second American species, the Neotropical Myloxenoides tandilensis Martínez, 1975, and confirmed this diagnosis except for the presence of one pair of palidia in the

Table 1. Comparison of the larval morphology of some genera of Pachydeminae.

\begin{tabular}{|c|c|c|c|c|c|}
\hline Genus & $\begin{array}{l}\text { Chaeotaxy } \\
\text { of raster }\end{array}$ & $\begin{array}{l}\text { Head } \\
\text { pubescence }\end{array}$ & $\begin{array}{l}\text { Sensory spots } \\
\text { in last antennal } \\
\text { segment }\end{array}$ & $\begin{array}{l}\text { Reduction of } \\
\text { metathoracic } \\
\text { claws }\end{array}$ & Reference \\
\hline Phobetus & $\begin{array}{l}2 \text { pairs of } \\
\text { longitudinal } \\
\text { palidia }\end{array}$ & $\begin{array}{l}\text { Long, fine } \\
\text { microsetae }\end{array}$ & Oval-shaped & Very small & $\begin{array}{l}\text { Ritcher } \\
1966\end{array}$ \\
\hline Myloxenoides & $\begin{array}{l}1 \text { pair of } \\
\text { longitudinal } \\
\text { palidia }\end{array}$ & $\begin{array}{l}\text { Long, fine } \\
\text { microsetae }\end{array}$ & Oval-shaped & Very small & $\begin{array}{l}\text { Vincini et } \\
\text { al. } 2000\end{array}$ \\
\hline Tanyproctus & $\begin{array}{l}1 \text { pair of } \\
\text { arch-shaped } \\
\text { palidia }\end{array}$ & $\begin{array}{l}\text { Short club- } \\
\text { shaped } \\
\text { microsetae }\end{array}$ & Oval-shaped & $\begin{array}{l}\text { Replaced by } \\
\text { a soft process }\end{array}$ & $\begin{array}{l}\text { Medvedev } \\
1960\end{array}$ \\
\hline Hemictenius & $\begin{array}{l}\text { No } \\
\text { defined } \\
\text { palidia }\end{array}$ & $\begin{array}{l}\text { Short club- } \\
\text { shaped } \\
\text { microsetae }\end{array}$ & Oval-shaped & Absent & $\begin{array}{l}\text { Medvedev } \\
1960\end{array}$ \\
\hline Pachydema & $\begin{array}{l}\text { No } \\
\text { defined } \\
\text { palidia }\end{array}$ & $\begin{array}{l}\text { Short club- } \\
\text { shaped } \\
\text { microsetae }\end{array}$ & Oval-shaped & Absent & $\begin{array}{l}\text { Lacroix } \\
2000\end{array}$ \\
\hline Ceramida & $\begin{array}{l}1 \text { pair of } \\
\text { arch-shaped } \\
\text { palidia }\end{array}$ & $\begin{array}{l}\text { Short club- } \\
\text { shaped } \\
\text { microsetae }\end{array}$ & Thread-like & Absent & This study \\
\hline
\end{tabular}


raster. They also list six other larval characters separating Myloxenoides from Phobetus. Unfortunately, this kind of detail is missing from most published descriptions of larvae of Palearctic genera (e.g., Medvedev 1960, Lacroix 2000). Better, standardized descriptions after Ritcher (1966) will be necessary in order to provide a key for the generic identification of Pachydeminae larvae. However, some characters can still be recognised (Table 1). For example, the Palearctic Pachydeminae do not present the longitudinal palidia characteristic of the New World genera. Ceramida and Tanyproctus have transversal, "arch-shaped" palidia, whereas no distinguishable palidia can be found in Hemictenius and Pachydema. The short, "club"-shaped setae covering the head capsule of Ceramida (Fig. 1c) are probably a synapomorphy of the Palearctic genera. Larvae of the New World Phobetus and Myloxenoides exhibit the long fine pubescence characteristic of Melolonthidae larvae (Ritcher 1966). The "thread"-shaped sensorial spots of the antennal apex of Ceramida are probably an autapomoprhy of the genus; the rest of genera present oval-shaped, elliptical spots. An interesting trend, already observed by Ritcher 1966, is the reduction in size of the metathoracic claw in Pachydeminae. For example, the metathoracic claws of Phobetus and Myloxenoides are much smaller than those in pro- and mesothoracic legs. The reduction is even more drastic among the Palearctic genera: in Tanyproctus the metathoracic claw has been replaced by a soft, small process, whereas in Hemictenius, Ceramida, and Pachydema the claw has disappeared and the tibia-tarsal segment ends in a highly dense, setose area (Fig. 2e).

\subsection{A review of the biology of Ceramida species}

Figure 3 summarizes the life cycle of Ceramida species based on laboratory and field studies of pest species Ceramida adusta and C. cobosi (Serrano et al. 1996, this study) as well as field observations on other species (Cobos 1951, Branco 1981, Lopez-Colón 1993).

Eggs (Fig. 4a): In the early spring (mid Aprilearly May), female Ceramida spp. migrate from
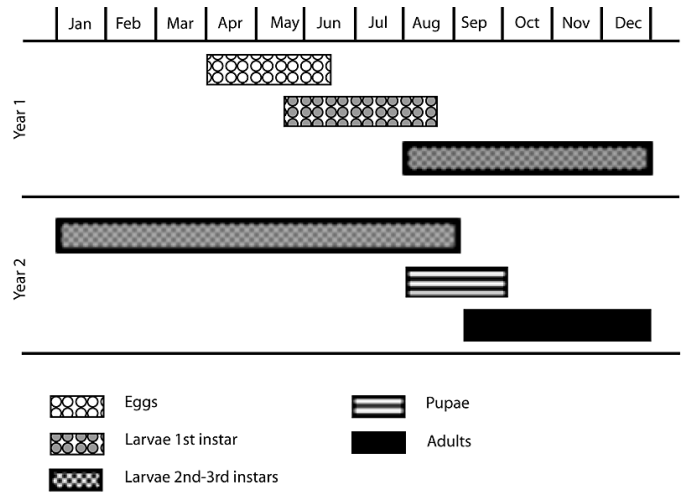

Fig. 3. A synthetic representation of the life cycle of Ceramida spp.

the deep soil layers $(50-100 \mathrm{~cm})$ where they overwinter, towards the plant roots $(30-70 \mathrm{~cm})$ for oviposition (Serrano et al. 1996). Each female deposits 40-45 eggs scattered around the plant root system. Eggs are deposited singly rather than in clusters, in contrast to other pest species (e.g., Melolontha; Alvarado et al. 1996). Females die after oviposition. The newly laid eggs are white and oval shaped $(2 \times 1 \mathrm{~mm})$, becoming more spherical $(3 \times 1.5 / 2 \mathrm{~mm})$ as they develop (Fig. 4a).

Larvae (Fig. 4b): Eggs start hatching in May, after two-three weeks of development, with the highest larval densities in June (Serrano et al. 1996). In the laboratory, first-larval instars $(0.5$ $\mathrm{cm}$ long) appeared after 15-30 days of development. Inspection of their digestive system showed that it was filled with earth so it is likely that first-larval instars feed on organic matter from the surrounding soil. Second and third larval instars (1-4 cm long) feed on the living root system of plants. Serrano et al. (1996) described larvae of $C$. adusta and C. cobosi feeding on olive and wine tree roots and we fed them on fresh carrot roots in the lab. Cobos (1951) and LópezColón (1993) recorded larvae of Ceramida bedeaui (Erichson, 1884) and C. adusta, respectively, feeding on roots of woody evergreen grasses. Larvae of other Pachydeminae genera such as Pachydema (Lacroix 2000) or Elaphocera Gené, 1836 (Cobos 1951), have also been collected in association with roots of grasses so this is probably their natural food. In the laboratory second and third-instar larvae showed a very aggressive behaviour and tried to bite when 


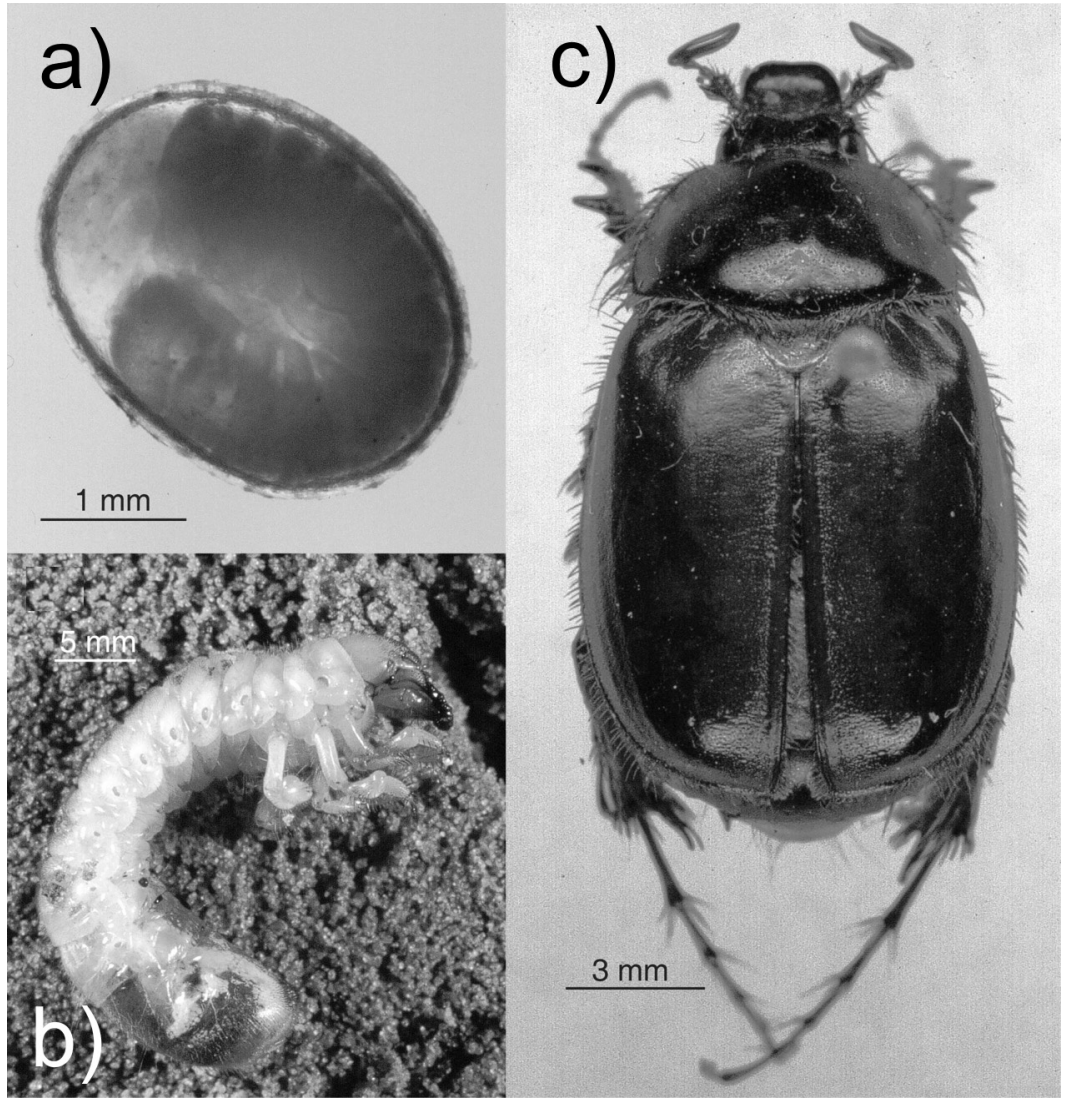

Fig. 4. Different stages on the life-cycle of Ceramida spp. - a. Egg with embryo inside, lateral view. - b. Third-stage larva, lateral view. - c. Male adult of C. cobosi, dorsal view. touched. If placed in the same recipient, one of the larvae kills the other. Lacroix (2000) recorded a similar behaviour for the larvae of Pachydema so this is probably a common behaviour in the subfamily. It would explain why Ceramida females lay eggs scattered around the plant roots rather than in clusters as in other Melolonthidae (Alvarado et al. 1996). Ceramida larvae were also more agile and active in the laboratory compared with other white grubs.

Adult (Fig. 4c): Based on field observations of C. adusta and C. cobosi, Serrano et al. (1996) suggested that larval development in Ceramida spans three years. In the laboratory, development from egg to imago took less than 20 months. However, rearing white grubs in a controlled environment and with constant food provision is likely to shorten the species life cycle (Ritcher 1996) so larval development is probably longer in the field. At the end of the summer (late Augustearly September) of the second (laboratory) or third (field) year of development, third-instar lar- vae migrate into the deep soil layers to pupate. In the laboratory, pupation was preceded by a premoulting quiescent period at the beginning of the summer, in which the larva ceases to feed and hardly moves. The pupal chamber is a naked oval earthen cell, slightly larger than the body, and pupation lasts approximately 30 days. Adults begin to emerge in late September-October with the first autumnal rainfalls. Mating flights take place during the autumn (October-November), sometimes extending to January, at the end of the rainy period (Serrano et al. 1996). Flights seem to be triggered by rainfall or by a highly saturated atmosphere (Cobos 1951, Branco 1981, LópezColón 1993, Serrano et al. 1996). Copulation is multiple and takes place beneath the soil surface (López-Colón 1993, Serrano et al. 1996). Adults seem to be more active at dusk or dawn. Males do not feed and die shortly after copulation, whereas females dig 70-100 cm into the soil for overwintering. Oviposition takes place in the spring (Cobos 1951, Serrano et al. 1996, this study), al- 
though López-Colón (1993) recorded a female of C. adusta ovipositing directly after copulation.

Soil texture and moisture are probably the most important factors determining larval survival and distribution. All field observations of Ceramida larvae have been recorded in loose, sandy soils (Cobos 1951, Branco 1981, LópezColón 1993, Serrano et al. 1996). The distribution of Ceramida in the Iberian Peninsula is restricted to the southwest (Atlantic) region, characterised by light, acid, sandy soils, whereas the sister-genus of Ceramida, Elaphocera (Sanmartín \& Martín-Piera 2003), is mainly distributed in the southeast (Mediterranean) region, characterised by heavy soils with a higher content of loam and clay (Sanmartín 2003). Desiccation is probably another important factor in larval survival. Fields under drip-irrigation were the most severely affected in Seville (Serrano et al. 1996) and soil desiccation was the main responsible for larval mortality in the laboratory.

Acknowledgements. I am especially grateful to Manuel Alvarado, Jose Serrano, and Antonio Durán (Departamento de Salud Vegetal, Seville) for their help in collecting specimens for this study and sharing with me their field observations. Lars Vilhelmsen is thanked for his comments on the manuscript and Jesus Romero for the illustrations. This work was supported by the Project Fauna Ibérica (PB95-0235-DGICYT) and the Swedish Science Research Council (VR 621-2003-3855).

\section{References}

Alvarado, M., Serrano, A., Durán, J. M. \& De la Rosa, A. 1996: Problemática de los gusanos blancos en el olivar de la provincia de Sevilla. — Bol. San. Veg. Plagas 22: 319-328.

Aragón-García, A., Morón, M. A., López-Olguin, J. F. \& Cervantes-Peredo, L. M. 2005: Life cycle and conduct of adults of five species of Phyllophaga Harris, 1827 (Coleoptera: Melolonthidae: Melolonthinae). - Acta Zool. Mex. 21: 87-99.

Baraud, J. 1992: Coléoptères Scarabaeoidea d'Europe. Faune de France et régions limitrophes, N 78. - Société Linnéenne de Lyon et Fédération Francaise des Sociétés de Sciences Naturelles, Lyon. 850 pp.

Branco, T. 1981: Contribution à la connaisance des Elaphocera Gené ibériques: quatre nouvelles espèces du Portugal (Col. Scarabaeoidea, Melolonthidae). Bull. Soc. Entomol. Fr. 86: 124-144.

Carne, P. B. 1951: Preservation techniques for Scara- baeidae and other insect larvae. - Proc. Linn. Soc. N S. W., Sydney 76: 26-30.

Cobos, A. 1951: Una observación biológica sobre el género Elaphocera Gené. - Bol. R. Soc. Esp. Hist. Nat. 49: 85-92.

Jameson, M. L., Micó, E. \& Galante, E. Evolution and phylogeny of the scarab subtribe Anisopliina (Scarabaeidae: Rutelinae: Anomalini). - Syst. Entomol. (in press).

Lacroix, M. 2000: Les Pachydema des Îles Canaries: Histoire, biogéographie historique et biologie larvaire d'une espèce inédite (Coleoptera, Scarabaeoidea, Melolonthidae). - Revue française d'Entomologie (N.S.) 22: $1-16$.

López-Colón, J. I. 1993: Observaciones sobre la reproducción de Ceramida abderramani (Escalera, 1923) (Coleoptera, Scarabaeoidea: Melolonthidae). — Zool. baetica 4: 75-79.

Medvedev, S. I. 1952: Larves des Scarabaeidae de la faune d'URRSS. - Faune SSRr, N 47, Moscow. 243 pp.

Medvedev, S. I. 1960: (Description of larvae of eight Scarabaeid species from the Ukraine and Central Asia.) Zoologichesky Zhurnal 39: 381-393. [In Russian with English summary].

Micó, E., Verdú, J. R. \& Galante, E. 2001: Larval morphology of some Anisopliini grain beetles with a key to their larvae (Coleoptera: Scarabaeoidea: Rutelidae: Anomalinae). - Eur. J. Entomol. 98: 311-320.

Ritcher, P. O. 1966: White grubs and their allies. A study of North American Scarabeid larvae. - Oregon State University Press, Oregon. 219 pp.

Sanmartín, I. 2003: Evolución biogeográfica de los Pachydeminae Paleárticos (Coleoptera, Scarabaeoidea) mediante análisis de dispersión-vicarianza. - Graellsia 59: 427-441.

Sanmartín, I. \& Martín-Piera, F. 1999: A morphometric approach to the taxonomy of the genus Ceramida (Coleoptera: Scarabaeoidea: Melolonthidae). - Can. Entomol. 131: 573-592.

Sanmartín, I. \& Martín-Piera, F. 2003: First phylogenetic analysis of the subfamily Pachydeminae (Coleoptera, Scarabaeoidea, Melolonthidae): the Palearctic Pachydeminae. - J. Zool. Syst. Evol. Res. 41: 2-46.

Serrano, A., Alvarado, M., Durán, J. M. \& De la Rosa, A. 1996: Contribución al conocimiento de Ceramida (Elaphocera) spp. (Coleoptera: Scarabaeidae) plaga de los olivares de la provincia de Sevilla. - Bol. San. Veg. Plagas 22: 203-211.

Verdú, J. R., Galante, E., Lumaret, J. P. \& Cabrero-Sañudo, F. 2004: Phylogenetic analysis of Geotrupidae (Coleoptera, Scarabaeoidea) based on larvae. - Syst. Entomol. 29: 509-523.

Vincini, A. M., Noemí-López, A., Álvarez-Castillo, H. A., Carmona, D. M. \& Manetti, P. L. 2000: Descripción de los estados inmaduros y la hembra de Myloxenoides tandilensis Martínez, 1975 (Coleoptera: Melolonthidae: Melolonthinae: Pachydemini). - Elytron 14: $39-51$. 